\title{
Ammoniation of straw by urea: influence of addition of soybeans and/or molasses on characteristics of treatment
}

\author{
JM Besle1, P Zwaenepoel2, M Chenost ${ }^{1}$, G Beaulieu², \\ JL Tisserand ${ }^{3}$, F Faurie ${ }^{3}$, N Grenet $^{4}$ \\ 1 INRA, Centre de Clermont-Fd/ Theix, Theix 63122 Ceyrat; \\ 2 CEMAGREF, "Les Palanquins" Montoldre, 03150 Varennes-sur-Allier; \\ 3 INRA-ENSSAA, 26, bd Dr-Petitjean, 21100 Dijon; ${ }^{4}$ ITEB-CRVZ de Theix, 63122 Ceyrat, France
}

Introduction - Our aim was to study the effects of adding molasses (to increase microbial urease) and/or soybeans on the efficiency of urea treatment of straw.

Materials and Methods - Wheat straw was treated in early September with, per $100 \mathrm{~kg}$ of DM, 6 or $8 \mathrm{~kg}$ of urea (U6, U8), $8 \mathrm{~kg}$ of urea + $0.8 \mathrm{~kg}$ of enzyme active soybean flour (Soyasol) (S) (U8S), or $8 \mathrm{~kg}$ of urea $+0.8 \mathrm{~kg}$ of $S+5 \mathrm{~kg}$ of beet molasses (M) (U8SM) or $3 \mathrm{~kg}$ of anhydrous ammonia (AA) (Armako method). U, S and water (to reach $30 \%$ moisture of treated straw) were sprayed on sections of round bales of 250 $\mathrm{kg}$, which were then put into plastic bags. After $18 \mathrm{wk}$, we determined nitrogen levels (Kjeldahl), urea content, organic matter digestibility of straw, by densitometry (OMDd) (Besle et al, 1989) and on sheep (OMD) (fed at $30 \mathrm{~g} \mathrm{DM} / \mathrm{kg}$ W.75), as well as voluntary intake.

Results and Discussion - Table I shows that ureolysis was improved with a low level of urea, much improved when $S$ was added and not significantly more so with molasses. OMDd variation seems to reflect the degree of ureolysis rather than the initial doses of urea. The increase in OMD was high with U6, but did not rise with further SM addition. Intake was particularly increased with SM. $N$ especially OMDd data obtained with AA were lower than those usually observed.

In conclusion, when straw was treated with urea, M only slightly enhanced the high $S$ effect on ureolysis and digestibility. SM considerably enhanced intake.

Acknowledgments - Thanks to ITEB and to the Agricultural Ministry (DPE, DGER) for its grant. Soyasol from SIO, 62, rue I Tourguenieff, 78380 Bougival.

Besle JM, Signoret C, Chenost $M$, Aufrère J, Jamot J (1989) In: Evaluation of Straws in Ruminant Feeding (Chenost $M$, Reiniger $P$. eds). CEC, Elsevier, London, 134-143

Table I. Characteristics of untreated (UT) and treated (see text) straw.

\begin{tabular}{lcccccc}
\hline & \multicolumn{7}{c}{ Treatments } \\
\cline { 2 - 6 } & UT & U6 & U8 & U8S & U8SM & AA \\
\hline & & & & & & \\
Ureolysis (\%) & - & $68.3^{\mathrm{a}}$ & $38.8^{\mathrm{b}}$ & $89.7^{\mathrm{c}}$ & $91.1^{\mathrm{c}}$ & - \\
Total N (g/kg DM) & $5.0^{\mathrm{a}}$ & $31.4^{\mathrm{a}}$ & $34.4^{\mathrm{b}}$ & $21.2^{\mathrm{c}}$ & $20.5^{\mathrm{c}}$ & $9.8^{\mathrm{d}}$ \\
OMDd (\%) & $42.0^{\mathrm{a}}$ & $49.9^{\mathrm{b}}$ & $47.8^{\mathrm{c}}$ & $50.2^{\mathrm{b}}$ & $52.5^{\mathrm{d}}$ & $45.9^{\mathrm{a}}$ \\
OMD (\%) & $52.3^{\mathrm{a}}$ & $62.7^{\mathrm{b}}$ & ND & ND & $63.5^{\mathrm{b}}$ & ND \\
Intake (g/kg W0.75) & $31.3^{\mathrm{a}}$ & $24.2^{\mathrm{b}}$ & ND & ND & $44.6^{\mathrm{c}}$ & ND \\
& & & & & & \\
\hline
\end{tabular}

